\title{
Elitism in Policy Planning on Village Government
}

\author{
A Kumalasari ${ }^{1}$, D G Suharto ${ }^{2}$, R H Haryanti $^{3}$ \\ Departement of Public Administration, Universitas Sebelas Maret, Surakarta, Indonesia ${ }^{1}$
}

\{ana_kumala.sari1@student.uns.ac.id $\left.{ }^{1}\right\}$

\begin{abstract}
Ideally, policy presents as a public preference or simply it is public goods, even in the smallest scope like the villager. However, the reality is that some policies of village governance have many disadvantageous to the villager. As a sample is in the Cikeruh Village regarding the recommendation letter of Cikeruh village Head about the flat house construction. The policy has caused pro and contra side among the villager, because the villager was surprised by the construction of an apartment and not flat house like before in letter recommendation, and some people in AMDAL zone did not feel involved in any discussion from the beginning related to the construction of the flat house. Village government plays an important role in mediating villagers with other stakeholders to make policy by involving the villager in every policy process from start to finish not otherwise dominating the policy process with others to get personal or group interests. The method used in this research is qualitative by using primary data in form of in-depth interviews of harmed villager because of the policy. The validity of data is done by triangulation method. The data is analyzed by adjusting and comparing between one informant and the other. The secondary data is collected through the study of the documentation in particular to documents related to the recommendation letter of the head of Cikeruh village about the flat house construction. The conclusion is that the villager is entitled to participate in any existing policy process. This research is intended to provide recommendation to the village governance to be wiser in policy process by involving the villager appropriate with the portion already regulated by the law.
\end{abstract}

Keywords: Elitism; Policy Planning; Village Government

\section{Introduction}

Elitism is the dominance of actors, where there are certain people who have the power to control a forum, group, or system. The special characteristics of elitism formulated by researchers combined the concept of the theory elite according to four scientists namely power, interests, the ruling class, and public silence according to Pareto, Mosca and Mills [1].

Elitism is not new in the policy process. It is undeniable that community culture is one of the strongest assumptions that can affect local democratic systems such as village governance in Indonesia since a long time ago. The results of research in some villages in Central Java show that although the reforms have been running since mid-1998, but the development of democratization in the village meet some of the following development points that can be a continuum that is:

- No progress,

- Silent Resistance, 
- Self-organization,

- Anarchist mass mobilization, and

- $\quad$ The development of civil society [2].

There are various forms of elitism that are often detected intentionally or unintentionally. Both in general government systems, leadership, decision-making, and even policy process. The existence of elitism forms that occur in the policy process can be seen through the actor's approach. The actor in question is the actor who really plays an important role in every process of the policy. The policy actors are as follows:

- Formal institutional actors (those who already have positions in certain institutions such as the President, Minister, Governor, Mayor, etc.), and

- Actual actors (policy advisors, peer groups of policymakers, mass media, interest groups, and scientists) [3].

Referring to the concept of elitism that has been formulated through some special characteristics, it can be said that one form of elitism in the policy process will be seen in the utilization of power that is very dominant by some policy actors. Where the power will be used to promote the interests of individuals and certain groups and will certainly move the public interest/community as a top priority.

From these forms of elitism, it can be seen how elitism can occur in the policy planning process. Looking further through the power of policy actors, it means that the policy actors have the power to determine who individuals will be involved in the policy process as a form of their elite power. In addition, certainly, the actors involved have various interests with their respective orientations are different too.

Simply stated that the actors to be involved are the actors whose respective interests will support each other. Meanwhile, judging from the position of all the existing actors, if classified as a ruling class, certainly not all actors are actors who govern an institution. That means the actors referred to as the elite can be classified as a smaller group. From this set of assumption analyzes, public silence will begin to be detected by questioning whether in these policy actors the public is involved or the time should be involved in the portion?

So what needs to be seen is whether the four distinctive features of elitism take place in any stage of the policy planning process or only in a few stages. As for whether in the four policy planning processes the actors engage the citizens with the correct portion as a form that the policy actors use their powers appropriately. Then is there any interest of the other party that precedence so that it will affect the actors to choose and determine who will be involved later in the policy planning process as the next stage.

The policy process is very important in every system of government. Important because in the policy process there are values of public needs are taken into account maturely. Ideally that the policy process is carried out through several steps and involves some actors who actually have a role in every consideration of the policy.

Policies should also be a public preference and not an elite even in small scope. The public preference in question is that policies should contain public needs rather than the needs of elites. However, in reality, one of the policies in Cikeruh village about the flat house development permit actually harmed the villager because the villager felt that they were not involved and the AMDAL concept is still unclear. 
As a first step, planning is very important because in planning all things about the policy are discussed. In planning there are four stages that will be done that in the planning stage consists of several activities such as:

- Identify policy issues for policy agenda,

- Planning, preparing policy-making methods,

- Selecting and setting up the policy formulation team, and

- $\quad$ Prepare for all needs for policy making including Procedure Operational Standard policy-making [3].

Policy planning is the key stage of determining which policy issues will be the policy agenda. That is why policy planning is important to engage the citizens in it. Why in the village government? In the data of Bappenas 2015 mentioned that the "Village Mandiri" in Indonesia amounted to $3.97 \%$ of the overall Village in Indonesia. In its development the Village Index was made with reference to Law Number 6 of year 2014 concerning Villages and used 201 Village potential data as a reference to key indicators of index compilers and synchronized with regulation of minister of interior number 39 of year 2015 on the Code and Territory of Government administration as the standard reference for the number of villages registered in Indonesia. In Law No. 6 of 2014 on Village, it is also mandated that village development aims to improve the welfare of rural communities, improve the quality of human life, reduce poverty through the fulfillment of basic needs, the construction of village infrastructure, the development of local economic potential, the utilization of natural resources and environment sustainability by bringing together togetherness, kinship and mutual cooperation to bring about the mainstreaming of peace and social justice.

Village governance has an important role in the development of democracy. This is because the village government is the spearhead of one of the benchmarks of the success or failure of regional autonomy in Indonesia. Therefore, for the realization of ideal village governance, it is important to collaborate with the concept of good governance. In the concept of good governance contains some basic things that need to be applied, some of which are: transparency, accountability, and responsiveness and community participation. Thus village autonomy and decentralization is not just a division of authority between levels of government but a more substantive government approach.In the main point, the village government has its own autonomy right to manage its household affairs. Based on Village Law number sixth 2014 is that the village should prioritize discussion to take any policy. When viewed from the concept offered by the village law, elitism should not happen. But the culture of society that is difficult to change seems to support the existence of elitism until now, especially in rural areas.

In addition, community life in the village is still strong in culture. Not to mention the influence of the New Order period that is still strong up until now against the political culture of villager. So that it can establish a certain political gap between villagers. As the identification of villager based on rural community stratification concept proposed by Hofsteede, namely:

- Village elites, consisting of lurahs, local and central officials, formal leaders and community leaders, teachers, political and religious figures, and rich farmers and

- Mass, which consists of middle farmers, farm workers, small traders, and craftsmen [4]. 


\section{Methodology}

The method used is qualitative by using primary data in the form of data collection through in-depth interviews to the aggrieved villager because of the policy. Data validity is done by triangulation method. The collected data is analyzed by adjusting the information of one informant and the other. Secondary data were collected through documentation study, especially policy documentation in the form of recommendation from village head of Cikeruh about flat house development.

\section{Result and discussion}

The ideal policy process is a policy process that begins with planning, where planning begins with identifying policies. However, in reality, what happened in the field was that the villager felt that they were not involved in the policy planning process of Cikeruh Village Head's recommendation letter on the construction of the flat house. This is evident from the public's shock when finding marketing brochures that circulate about an apartment and not rusunami that will soon be built in the area of their village.

Starting from there, some youth of the cadets who are considered to be aware of this issue are trying to clarify the village government. The village government responded that there was already a special team established earlier to conduct field reviews related to the construction of the apartment. The people do not even know what happens in the stage of identifying policies, which should be the people getting involved from there. It can be seen from the socialization that was held but only a few people present.After that a special team formed by the village government that had been following the socialization is also used as a team of policy formulators letters recommendation development permit flat house.It proves that the policy planning process is precisely started by the secret ways by the village government. Secretly it means that only a few people know about the release of this flat house development permit policy.

From the description above, it can be seen that the dominance of actors in the use of power-oriented interests and the existence of classes that govern the planning process. The use of power was made to prepare a special team for field review before the policy of recommendation letter of development permit flat house issued. After that the special team is invited to identify the policy issues in the form of socialization. Then the special team formed by the village head of Cikeruh at the time consisted of his beliefs who were at the same time subordinate to the structure of the village government.

Then there is a certain compensation gained by the people in the special team in return for issuing a letter of recommendation of the flat house construction. This is what indicates the personal interest of each of the several people who put forward. Then the existence of the ruling class can be seen from a special team formed by the village head of Cikeruh at that time. The village head has the power to decide who should be involved in the policy planning of the development letter of the flat house development permit as an elite, and the governed are the special teams he formed and the people who were unaware of the policy planning action.Not to mention when talking about how policy actors work as government elites. Elites are seen as a group of creators of the order which is then embraced by all parties. In a newer approach, the elite is seen as a group that gathers government officials. The sense of the elite is matched by the leader or decision maker [5]. As a decision-maker, the elite will undertake various coordination in various important activities related to the current government system. One of 
them is in the policy process, where a very complex policy process definitely requires reliable actors.

Actors are every parties who engage (not just "involve" or "participate") in the policy process. And the word "engage" means effective involvement; means it is the influential participants [3]. So it can be said that policy actors are those who are accountable for every policy milestone and overall process. From the idea, it is also very well detected that the role of the actor in each policy is one of the most decisive indicators of public policy. The main existential problem of every resident in a sustainable $21^{\text {st }}$-century city/community is to find out how to be useful in the world and its aspirations to be noticed [6]. The United Nations defines "sustainability" as "development without burdening future generations" [7]. Participation can promote social sustainability, is beneficial for effective decision making and produces better policies [8].

Social change has significantly increased the importance of public participation [9]. Public participation is defined as an initiative carried out independently of government policy by stakeholders from civil society or the private sector to provide public involvement in management decision-making and processes [10]. Incorporating participatory elements into the decision-making processes has become a symbol of (post) modern governance [11]. Public participation is increasingly institutionalized in terms of environmental governance throughout the world [10]. Participation has been widely studied, related to issues such as development, project planning, community-based initiatives, policy making, governance and implementation. Participation can improve the quality of policy/science, based on the knowledge and experience of the actors involved [12].

\section{Conclusion}

The conclusion is two of the four stages of policy planning that exist, the dominance of actors in it is the stage of identifying policies and selecting and preparing the team of policymakers. Then from the four special characteristics of elitism that exists, which occurred in the policy planning of the development permit letter of this flat house development are three of which is the presence of power, interests, and the ruling class.

It is also important that the villagers are entitled to participate in every existing policy process including policy planning. This research is intended to provide recommendations to the village government to be wiser in issuing policies by involving the villager in accordance with the portion already set in the Law. Because the village government is a mediator between villager with parties outside of the village to conduct cooperative relations in any form.

There are many things that can make elitism take place in the policy process. As it was pointed out in the previous chapter that village life is still strong in culture. Not culture in general. But more for the habits of the villagers. Like political culture, when the culture of a society is the attitude of society to politics itself. Then a culture that still needs time to be applied well to the villager.

One of the results of the research even said that the culture of Indonesian society is not significant, because it can still be realized by paternalism, parochialism has a strong nature of strength, and patrimonialism is still growing very strongly.

Acknowledgments. Acknowledgments go to the Cikeruh village government and the people who have been willing to be interviewed as informants, as well as people who have assisted this research which cannot be mentioned one by one. 


\section{References}

[1] A. H. Birch, The Concepts and Theories of Modern Democracy. London and New York: Physchology Press, 2001.

[2] K. Suwondo, Perubahan Pola Pemerintahan dan Kepemimpinan. Salatiga: Lokal Forsa Pustaka, 2002.

[3] R. Nugroho, Policy Making Mengubah Negara Biasa menjadi Negara Berprestasi. Jakarta: Kompas Gramedia, 2015.

[4] B. Mulyawan, "Budaya Politik Masyarakat Indonesia dalam Perspektif Pembangunan Politik,” J. Aspir., vol. 5, no. 2, pp. 13-20, 2006.

[5] M. Ramli, "Patronase Politik dalam Demokrasi Lokal (Analisis terhadap Terpilihnya Hj. Marniwati pada Pemilukades di Desa Jojjolo Kecamatan Bulukumba Kabupaten Bulukumba)," UIN Alaudin Makassar, 2016.

[6] S. A. Timashev, V. N. Alekhin, L. V Poluyan, I. Fontanals, and A. Gheorghe, "Transforming Yekaterinburg into a Safe, Resilient-Smart and Sustainable City," IOP Conf. Ser. Earth Environ. Sci., vol. 177, p. 12001, Aug. 2018.

[7] G. Alibekova, A. Panzabekova, Z. Satpayeva, and N. Abilkayir, "Sustainable development issues of Almaty as the largest metropolis in Central Asia," IOP Conf. Ser. Earth Environ. Sci., vol. 177, p. 12010, Aug. 2018.

[8] M. Teder and P. Kaimre, "The participation of stakeholders in the policy processes and their satisfaction with results: A case of Estonian forestry policy," For. Policy Econ., vol. 89, pp. 54-62, Apr. 2018.

[9] S. A. Wagner, S. Vogt, and R. Kabst, "The future of public participation: Empirical analysis from the viewpoint of policy-makers," Technol. Forecast. Soc. Change, vol. 106, pp. 65-73, May 2016.

[10] J. Wu, M. Xu, and P. Zhang, "The impacts of governmental performance assessment policy and citizen participation on improving environmental performance across Chinese provinces," J. Clean. Prod., vol. 184, pp. 227-238, May 2018.

[11] C. Maier, T. Lindner, and G. Winkel, "Stakeholders' perceptions of participation in forest policy: A case study from Baden-Württemberg," Land use policy, vol. 39, pp. 166-176, Jul. 2014

[12] C. Hirsch, "Makers and shapers of environmental policy making: Power and participation in forest legislation in Bolivia," J. Rural Stud., vol. 50, pp. 148-158, Feb. 2017. 